\title{
Conceptual and Legal Framework for Promotion of Education for Sustainable Development: Case Study for Ukraine
}

\author{
Tetiana Hudima ${ }^{1}$ and Vesta Malolitneva ${ }^{2}$,
}

\begin{abstract}
Promoting the sustainable development is currently a key global issue posing a challenge to all of us on personal, professional and political levels. The education plays a major role in this path, in particular the education for sustainable development (ESD). The traditional one-way transfer of knowledge is no longer sufficient to inspire the students to behave as responsible citizens. This article suggests a number of competencies, which must serve as a basis for ESD, as well as application of the multiple intelligence theory as a mechanism for implementing the competencies derived by students from ESD at the basic education level. It is proved that security competencies in the broadest sense (covering all levels, from personal to the global space) should also be included in the modern educational process. As for the university education, it is required to explain the concept of "sustainability" to all specialties without exception, including the political scientists, engineers and others. This is particularly important for training of experts dealing with the economic law issues. A lack of economic analysis in modern legal studies and development of regulations results in writing and adoption of idle laws hazardous for the country. To upgrade the education system in Ukraine, it is appropriate to develop the National Strategy on Education for Sustainable Development and its implementation plan based on the global Sustainable Development Goals. It is required to switch from traditional education to the model focused on sustainable development with the underlying extensive interdisciplinary knowledge based on an integrated approach to the development of society, economy, and environment. Implementation of this strategy should consider the adaptive nature of the regional education component, in particular the economic features of a relevant region. It is important to focus on the learning processes underlying the circular economy.
\end{abstract}

Keywords: sustainable development, society, economy, environment, circular economy, education for sustainable development, sustainability, economic law.

\section{Introduction}

Promoting the sustainable development is currently a key global issue. A key role in this process should be played by the education (Strategy, 2015). Many scholars and practitioners believe that it should become the foundation of sustainable development of any country. This idea is penetrating most international documents, including the $21^{\text {st }}$ Century Agenda (Chapter 36), the Declaration adopted at the World Summit for Sustainable Development in 2002, Magna Charta of European Universities (1988); Talloires Declaration of University Presidents for a Sustainable Future(1990); Halifax document «Creating a Common Future: an Action Plan forUniversities» (1991);

| ${ }^{1} \mathrm{PhD}$., senior researcher at the Institute of Economic and Legal Research of the National Academy of Sciences of Ukraine, Kyiv.

$\mathrm{PhD}$., senior researcher at the Institute of Economic and Legal Research of the National Academy of Sciences of Ukraine, Kyiv. 
Urgent Appeal from the CRE to the Preparatory Committee of UNCED (1991); Copernicus «Universities Charter on Sustainable Development» (1994); Luneburg Declaration on Higher Education for SustainableDevelopment (2001); Ubuntu Declaration on Education and Science and Technology forSustainable Development; GrazDeclaration on Committing Universities to Sustainable Development (2005); G8 University Summit Sapporo Sustainability Declaration (2008); G8 University Summit: Statement of Action (2010) and so on.

However, the analysis of modern education in practice, particularly in Ukraine, proves that it pursues the opposite direction. Educational institutions have currently become a part of a global mechanism for public consumption (and, most dangerously, unsustainable over-consumption). Such a society is based on the waste of public resources, many of which are non-renewable. Consumption is the goal, while the profession, training, and personal growth only artificial means to satisfy the "needs to consume." Such a focus often leads to a loss of spiritual attitudes, moral and intellectual capacity. Profit becomes the ultimate goal of the existing system. Education in this system is a paid market service. Its new standards aimed at the training specialization do not change the situation. Even an active introduction of sustainable development courses in high schools of many countries (Sweden, Norway, Great Britain, etc.) does not produce the desired result.

The fact is that today many countries, including Ukraine, have not recognized officially the role of education in achieving sustainable development yet, there is no mechanism and legislative framework to promote such an education into specific educational practices. The problem also lies in methodological approaches, when in the environmental and educational process, the priority is given to the professional function of environmental education (providing the student with the required level of knowledge, abilities, skills, competencies) to the detriment of the ideological one (shaping a moral and environmental imperative in the human mind).

\section{Literature review}

Such scholars as Alekseev S., Aleixo Ana Marta, Ankuda S., Argunova M., Azeiteiro Ulisses Miranda, Bolshakov B., Bonnett M., Bulyhina T., Gorokhovatskaya N., Doroshkevych A., Kovaliova T., Kundas S., Lawthomb Rebecca, Leal Susana, Prowsec Alicia, Randlesd Sally, Tzoulasa K., Ursul A., Ursul T., Vargasa Valeria Ruiz, Wright T. et al. have dedicated their works to the analysis of various aspects of implementation education for sustainable development. However, the issues of the features of reorienting the consumer education to sustainable development education are not highlighted adequately yet. In the above studies, the process of education for sustainable development is disclosed by the authors mainly through the study of specific environmental subjects, which often do not have a specific ideological, methodological, value component, interdisciplinary connections, and not related to the practical activity of future specialists to address the environmental and developmental issues. Development of conceptual foundations of environmental education for sustainable development in general and their implementation is pending the phenomenological analysis, description of specific situations, highlighting the relationships and patterns. 
The above issues require further analysis and study. This is the purpose of the given study.

\section{Methodology and research methods}

In order to achieve the stated aim of the article and to ensure the scientific validity of the research results, a set of general and specific scientific methods was used. Taking into account the complexity and multidimensional character of the subject of research, modern methodological approaches have been applied: dialectical, formallogical, hermeneutic, comparative legal, praxeological, simulation and prognostic, generalization.

The use of the dialectical method has provided the disclosure of the theoretical and methodological basis for understanding the essence of education for sustainable development. The application of the formal-logical method made it possible to identify a number of competencies on which education for sustainable development in Ukraine should be based. The use of the hermeneutical method made it possible to analyze the content of the norms in international acts and norms (already implemented and/or to be implemented in the acting legislation) that reflect the impact of the European experience in education for sustainable development on the national realities and peculiarities of the modern education paradigm in Ukraine. The application of the comparative legal method provided an opportunity to analyze the features of education for sustainable development in the EU member states and to consider the specifics of its development and functioning. The praxeological, simulation and prognostic methods were used to determine the prospects for the development of education for sustainable development in Ukraine, taking into account the current global challenges. The generalization method was used to formulate conclusions, recommendations and suggestions.

\section{The essence of education for sustainable development}

Until now, the main focus of a State has been obtaining the basic education by all. However, in today's complex world with a serious existential threat, such as climate change, the demand for education going beyond the acquisition of knowledge and skills to find a job started growing.

Undoubtedly, modern education systems continue to focus on the mechanistic outlook of the world and the analysis of certain life aspects. However, a new approach is needed, allowing to see the world as a whole, analyze the relationships, interdisciplinary nature, and holistic view. We should switch from the simple transfer of knowledge and skills required for the existence of a modern society to the readiness to work and live in the rapidly changing conditions, and to participate in planning and predicting the consequences of various actions. This approach can be provided by the education for sustainable development (hereinafter - the ESD).

The education for sustainable development usually means education promoting a shift in knowledge, skills, values and attitudes in order to ensure a more sustainable and fair society for all (UNESCO, 2018). Such education aims to empower and provide the required "tools" to the present and future generations to meet their needs, using a 
balanced and integrated approach to economic, social and environmental dimensions of sustainable development. ESD is education of interdisciplinary nature. No discipline can consider sustainability on its own. They all (disciplines) must make their contributions individually or collectively. There must be a relationship where sustainable development should be integrated into education, and education into sustainable development, respectively.

ESD should focus on addressing the issues such as climate change, poverty and sustainable production, so that the students can understand and meet the challenges of the dramatically changing world. In this context, the traditional one-way knowledge transfer is no longer sufficient to inspire the students to behave as responsible citizens. ESD provides for a comprehensive rethinking of the learning environment.

Education for sustainable development - global dimension. In November 2014, UNESCO launched the Global Action Programme on ESD (UNESCO, 2018). Its tasks include the reorientation of education and training so that everyone has the opportunity to acquire knowledge, skills and values enabling to promote sustainable development; strengthening the education and training in all programs and activities promoting the sustainable development. ESD is integrated into many global policy documents and conventions on sustainable development. For example, Art. 13 of the Convention on Biological Diversity, ratified by Ukraine in 1994 (Convention, 1994), p. 11 and Art. 12 of the Paris Agreement, ratified by Ukraine in 2016 (the Paris Agreement, 2015) and several other documents.

Education for sustainable development is at the heart of 17 Global Sustainable Development Goals 2030 (Goals, 2016), because achieving these goals requires a profound transformation in the way we think and act. ESD is explicitly stated in Goal 4, "Promoting an inclusive and equitable high-quality education and encouraging the lifelong learning opportunities for all" and task 4.7 provides that all students must gain the knowledge and skills required to promote a sustainable development, including through the training on sustainable development and sustainable living, human rights, gender equality, promoting a culture of peace and non-violence, global citizenship, peace and awareness of the value of cultural diversity and the contribution of culture in sustainable development by 2030. It means that ESD serves as one of the means to achieve and implement all other sustainable development goals. This was confirmed when, during the $74^{\text {th }}$ session, the Second Committee of the UN General Assembly adopted a resolution on ESD within Sustainable Development Goals (SDG), which has clearly recognized and emphasized the role of ESD as an integral part of the SDG on the quality of education and a key tool for all the other sustainable development goals (Agenda, 2030).

Therefore, (1) education is a critical element to overcome poverty (Goal 1: No Poverty); (2) various educational projects and programs enhance the skills and abilities to use natural resources more effectively and help improve the energy efficiency and use of renewable energy sources (Goal 6. Clean Water and Sanitation, and Goal 7. Affordable and Clean energy); (3) there is a direct link between such areas as economic growth, entrepreneurship, skills needed in the labor market and education (Goal 8. Decent Work and Economic Growth). 
Education can make a significant change in production models (e.g. for the circular economy development), give preference to more sustainable goods and prevent wastes (Goal 12. Responsible Production and Consumption), etc. (UNESCO, 2018). This education is not about sustainable development, but rather for (the sake of) sustainable development.

\section{Competencies of Education for Sustainable Development}

Students should become "sustainable citizens" (UNESCO, 2018). They must be able to understand the tradeoffs between the sustainable development components and associated risks. An approach focused on action is required. To become a "sustainable citizen", it is expedient to develop the core competencies. They are effective for ESD evaluation.

According to Franz Weinert's definition, the competencies are "the cognitive abilities and skills available to or learned by individuals to deal with certain problems related to the motivational, volitional skills, social commitment and ability to solve the problems in varying situations successfully and responsibly (Weinert et al., 2001). Whereas competencies are related to the goals, intentions and objectives, they must be manifested in the individual's actions. Accordingly, the competencies can be converted to the desired results and evaluated.

Core ESD competencies were highlighted by many researchers and practitioners. Among various approaches, one of the first competency concepts, "Gestaltungskompetenz", developed by Gerhard de Haan und Dorothee Harenberg in the late 1990s, should be noted. It included eight key competencies (such as: (1) forward-thinking, (2) interdisciplinary work; (3) cosmopolitan perception, transcultural understanding and cooperation; (4) involvement skills, (5) planning and self-fulfillment, (6) ability to empathize, (7) self-motivation and motivation of others; (8) remote apprehension of individual and cultural models) and was aimed at identifying the unsustainable development problems (Haan, 2002; Harenberg, 2001).

Since 2008, "Gestaltungskompetenz" has allocated twelve sub-competencies learned by the students for a sustainable future: (1) cosmopolitanism and integration of new prospects; (2) knowledge creation; 3) forecasting, analysis and assessment of events; (4) interdisciplinary knowledge; (5) identification and weighing of risks, hazards and uncertainties; (6) teamwork; 7) consideration of conflicting objectives when planning strategic actions; (8) participation in making collective decisions; (9) self-motivation and motivation of others (involving all in the activity); (10) shaping one's own opinion; (11) use of the ideas of justice as a basis for decision-making and actions; (12) the ability to plan and act independently. These core competencies are particularly relevant if we consider sustainability as a form of change in society, requiring the active involvement of competent citizens; in this context, self-development contributes to social progress (Barth, 2007).

Podger D. et al. referred to the dispositions of a higher order, not to the competencies, and offered the ESD to teach "the whole person" and maintain sustainable "habits of mind", allowing to use the systemic thinking (Podger et al., 2010). The further work on the basis of G. de Haan's core competencies and "systemic thinking" was continued by 
Reid A. He offered a classification and a synthesis of systematic, proactive, regulatory, strategic and interpersonal competencies (Reid et al., 2011). Wiek A. broke the competencies down into clusters, which is a useful approach to provide the contextualization and develop specific competencies while maintaining the categories (Wiek et al., 2011). The competencies developed by scientists later were focused mainly on formal learning in higher education (Mochizuki et al., 2010; Cebrián et al., 2015; Vare et al., 2019; Waltner et al., 2019; Wilhelm et al., 2019).

In 2018, UNESCO released the Issues and trends in education for sustainable development. This paper defined the key competencies required to transform a person's own lifestyle and contribute to the transformation of society for sustainable development. They include the systematic thinking (the ability to recognize and understand the relationships, to analyze complex systems, to have an understanding of the ways in which the systems are embedded into various areas and to deal with uncertainty); predictability competency (the ability to understand and evaluate several aspects of the future - likely, probable and desirable, and create one's own vision of the future, to apply the precautionary principle, to assess the consequences of actions, risks and potential changes); management of complex tasks; critical thinking, acting fairly and environmentally friendly; the competency of cooperation (the ability to learn from others, understand and respect the needs and actions of others (empathy), understand and be sensitive to others, address conflicts in groups), interdisciplinary work, communication and use of mass media, planning and implementation of innovative projects, assessment, tolerance to ambiguity and frustration (relates to the ability to cope with conflicts, competing goals and interests, contradictions and failures) (UNESCO, 2018).

Recently, more and more authors stress the further competencies, such as knowledge about our planet condition, reasonable decision-making, modeling the sustainable behavior and transformation social changes (Glasser et al., 2016).

An integrated problem-solving competency (the ability to use different schemes of addressing the sustainable development issues and the development of a comprehensive and fair solution to the problems by integrating the above competencies) is equally important. While traditional teaching studies mostly past experience, the ESD should focus on potential problems in the future, in order to be able to not only solve the current problems but also to prevent their occurrence. In this regard, an important component of the ESD should be forecasting, modeling, strategic planning and design. This is a list of core competencies essential for sustainable development and not central to the formal education.

Given the fact that formation of a global world is associated with occurrence of new threats and dangers of the planetary scale, which can cause anthropogenic global disaster, when switching to sustainable development, security ceases to be just one of the development conditions, and becomes an integral part of it. Currently, inclusion of safety issues in education applies only to certain parties and certain education courses and areas, mainly related to national, military, technological security, safety engineering, life safety, and more patriotic education. However, there is no general education program on security in the broadest sense, not to mention with regard to its transition to sustainable 
development, either in our country or abroad. However, it appears necessary not only for any state, but also for the whole world community (Ursul et al., 2016).

Security education cannot and should not be limited only to the creation of life safety, national security, technological security etc. departments at universities, as well as the corresponding training courses. The security issue affects almost all subjects and methods of disciplines taught, as well as courses, regardless of which branch of science they are related to. Therefore, competencies related to security in the broad sense (covering all levels, from personal to the global space) must be included in the whole modern educational process.

Therefore, the idea of ensuring security through development (or rather through sustainable development), particularly in Ukraine required a new legal registration and especially the improvement of the Law of Ukraine on National Security of Ukraine. This law should contain the basic concepts required for its enforcement and further development of all areas of security science.

It should be noted that all competencies are interrelated and interdependent. They allow evaluating the ESD results. However, ESD eventually aims to promote the transformative learning, learning by which a person begins to act sustainably. One certainly should start with a basic education. In this case, perception of the core EDS competencies by all students without exception is very important. It is required not only to make the child's education at school more effective, but also enable it to ensure its continued interest and enthusiasm for learning.

\section{The mechanisms of assimilation and implementation of ESD competencies by students}

Today, there are various mechanisms of assimilation and implementation of competencies derived from the ESD by students. One of the most successful, in our opinion, is the use of a multiple intelligence theory, revealing a possible way of the educational process individualization. The fact is that a person has not the only so-called "general intellect" but a series of intellectual abilities constituting a verbal, logicalmathematical, visual, kinesthetic, interpersonal, intrapersonal, musical, naturalistic and existential types of intelligence. Each of these intelligence types has its own structure, function, language and therefore present a special development potential.

The principle underlying the modern education is the principle of teaching all to everything. The duty of the school is to ensure the mastering of a state education standard by each student. In this situation, the teacher is probably most concerned with the question of how to make the standard mastering more individualized, and therefore more effective. School program emphasizes mainly two types of skills, i.e. verballinguistic (mostly in writing) and logic-mathematical. However, Howard Gardner (multiple intelligence theory author) believes that there are many other talents and knowledge, which can enrich our lives and help us to communicate with the surrounding world effectively. He argues that everyone has at least nine types of intelligence, expressed in varying degrees (Gardner, 2007) (Fig. 1). 


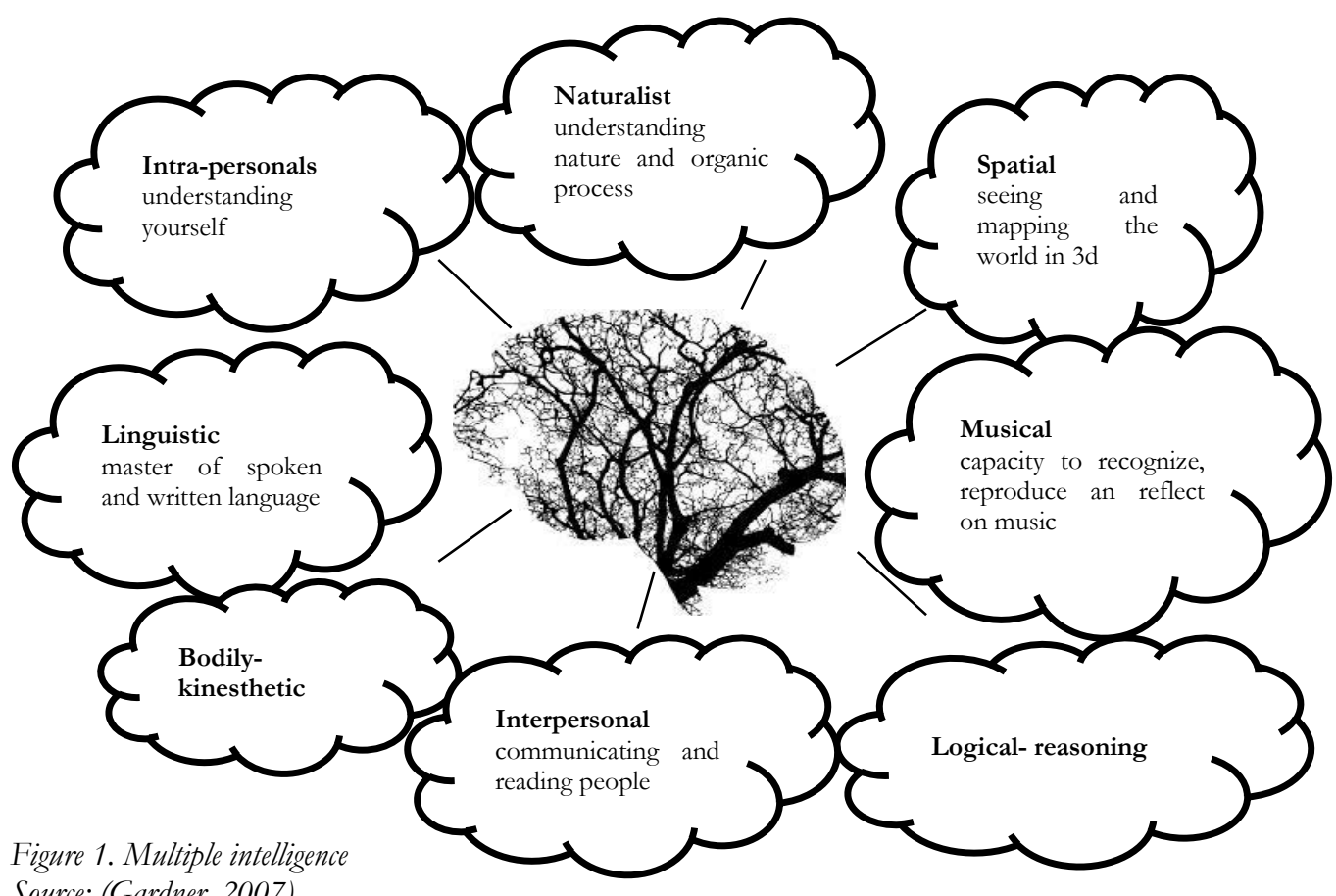

Source: (Gardner, 2007)

Some people have several well-developed skills, others experience difficulties in the manifestation of many of them. Most of us are somewhere in between, there is one or several abilities that we demonstrate with ease, some appear under normal efforts and one or more - under great effort only. Leveling these important aspects leads to the fact that a significant number of students fails to show positive results during training. They do not perceive and are not interested in perceiving information at the appropriate level. The reason for it is multiple mental faculties, through which we can implement the curriculum, as well as teach and develop the existing core competencies in students. Many scientists agree that learning is not only about the cognitive, but also about the non-cognitive aspects; education - is not only rational education. Various methods of physical, mental and emotional interaction with the world will contribute to the study and application of skills in real life. Therefore, school curricula must be based on the multiple intelligence theory. This will enable successful assimilation and implementation of ESD competencies by all students (in view of their personal level).

As for the university education, it is required to explain the concept of "sustainability" to all specialists, without exception, including the political scientists, engineers and others. Currently, many specialties negate this issue, because they do not see the connection between their professional activities and the environment. However, there is no doubt that there is a need to communicate the value of sustainability to different groups of students. In general, sustainable development involves several disciplines, such as environment, biology, medicine, nutrition, agronomy, geography, engineering, architecture, sociology, psychology, political science, history, law, economics and business etc. Given the sustainable development complexity, SDG cannot be studied in isolated disciplines. It should be remembered that ESD can be considered 
interdisciplinary not when it is provided by a combination of subjects, but only when the coordination and coherence of these subjects is ensured (Summers et al., 2005).

Therefore, the scientists from different disciplines need to combine their scientific knowledge, tools and approaches to help society in solving the urgent problems of sustainability. In particular, if we take the teaching of legal profession, the students should be taught that every legal norm, a fundamental idea must be based on the three pillars of sustainable development, i.e. a thorough economic analysis and analysis of social and environmental issues which it (norm/idea) can affect one way or another. This is particularly important for training of experts dealing with the economic law issues. A lack of economic analysis in modern legal studies and when developing the regulations results in writing and adoption the idle laws, hazardous for the country.

Further, it is required to dispel the widespread notion that sustainability is mainly relevant for industrialized countries, while the developing countries do not need to switch to ESD. According to scientists, sustainability is not a major problem in some countries, given the other, more pressing economic and political issues. Still, the countries for which the areas such as tourism and agriculture are important, may benefit from the transition to sustainable development. Obvious examples are Kenya (which largely adopted the sustainable tourism principles), India (showing a good progress with regard to sustainable agricultural practices), and Mauritius (where sustainable land use improved its ability to meet the demands of tourism) (Walter et al., 2019).

Also, it is important to note that ESD is not just a matter of learning about sustainable development and the inclusion of new content in lessons and classes. Schools and universities need to position themselves as experimental sites of learning for sustainable development, and thus have to operate in order to implement the sustainable development principles. It means that educational institutions must be transformed to become a role model for students, such as eco-schools or green campuses. For example, in Croatia, according to the law on pre-school education, it is mandatory for all kindergartens to integrate environmental development in their plans and curricula (the Ministry of Environmental Protection of Republic of Croatia, 2011). Another interesting experience is creation of an eco-school. International Eco-School Program was launched in 1994 by the International Organization for Environmental Education in response to the UN Conference on Sustainable Development 1992. As of June 2019, such schools existed in 67 countries, and their number exceeded 51 thousand (Eco-Schools, 2019). The program methodology is based on 7 steps, including the creation of a special environmental council, study of the environmental situation at school, development of the action plan (formulating the work objectives and specific practical steps to reduce the harmful effects and improve the environment, such as separate collection of certain types of waste and their recycling etc.; it is important to have realistic plans, which can be performed during one school year), monitoring and evaluation of plan performance, inclusion of environmental issues in school courses, cooperation with other organizations (libraries, educational institutions, entities, etc.), for example, to conduct joint activities; formulation and adoption of the Environmental Code (Eco-schools. Keep Britain tidy, 2019).

Still, as noted above, ESD is not just about the environmental component, but also about the economic and social one. In this context, the concept of education should be 
changed. Universities must be specialized in training the future entrepreneurs and aim at developing the students' entrepreneurial mindset, whereby the graduates would be able to implement their first startups. This may include student grants. A good example of it is the Loughborough University in the United Kingdom, which is a kind of laboratory to start one's own business (Petrakov). However, we must immediately develop entrepreneurial thinking based on the Sustainable Development Goals.

The undoubted leaders in ESD are Sweden and Germany, where ESD is developing on the basis of environmental education.

\section{Education for sustainable development in Ukraine}

Ukraine, like other UN member states, has joined the global sustainable development process. Legal acts on education do not recognize the decisive role of education in the sustainable development goals achievement and do not require the reorientation of existing curricula in the direction of social, environmental and economic knowledge in their interrelations. At the same time, there is a tendency in Ukraine towards the 'ecologization' of education content itself. Back in 2001, the Board of the Ministry of Education and Science of Ukraine adopted a decision "On the Concept of Environmental Education in Ukraine", the provisions of which did not find their broad expression in the basic legal acts on education, and were implemented at the level of courses and disciplines of individual educational institutions. Currently, the Law of Ukraine "On Education" defines the ecological competence among the competences necessary for successful life. The Law of Ukraine "On Higher Education" among the main tasks of higher education establishes the formation of environmental education. However, it should be noted that the aforementioned Concept and Laws of Ukraine, providing for a certain level of environmental education, take into account only one component of sustainable development, namely ecological without interdependence with social and economic pillars.

To upgrade the education system in Ukraine, a National Strategy on Education for Sustainable Development and its implementation plan are needed. It is anticipated to switch from traditional education to the model focused on sustainable development, with the extensive interdisciplinary knowledge, based on an integrated approach to the development of society, economy and environment. Implementation of this strategy will require consideration of the adaptive nature of the regional education component, taking into account, for example, the economic characteristics of the relevant region.

The training topics shall be determined by the Sustainable Development Goals. The Roadmap for Implementation of the Global Action Programme on ESD identifies the following key training topics: climate change, biodiversity, reduction of morbidity risks, as well as sustainable consumption and production (UNESCO, 2014). In light of the environmental and economic problems existing and remaining unresolved in Ukraine, it would be appropriate to focus on sustainable consumption and production, corresponding to Goal 12. For example, the student must understand how individual lifestyle affects the social, economic and environmental development; understand the production and consumption processes and their relationship (supply and demand, CO2 emissions, waste generation, working conditions etc.); understand the roles, rights and 
responsibilities of various stakeholders in the production and consumption (media, advertising, entities, consumers, government and local authorities, etc.). In this case, the student is able to communicate the need for sustainable production and consumption, may feel responsibility for the environmental and social consequences of their own behavior as a manufacturer or consumer. At the same time, the student can evaluate and participate in decision-making processes of state procurements and influence them, able to promote a sustainable production model, and able to act as an active stakeholder in the market. The practical aspect of such training will include, for example, calculation and evaluation of one's own environmental impact, analysis of different products using the product lifecycle analysis, run a student company manufacturing the sustainable products, role games with various roles in the trading system (producer, consumer, advertiser, waste manager etc.) and so on (UNESCO, 2018).

It is very important to focus on the teaching the processes underlying the circular economy. Circular economy is attracting attention as a potential means of achieving sustainable development. As an alternative to traditional linear economy (take, made and dispose of), this economy promotes the use of resources as long as possible, getting the maximum value when using the products, followed by a rehabilitation and regeneration of products and materials at the end of each their lifecycle (WRAP).

Therefore, the ESD will require a reorientation from providing knowledge to the analysis of problems and finding possible solutions. Therefore, in education, while maintaining a traditional focus on teaching certain subjects, it is required to provide opportunities for interdisciplinary analysis of situations arising in everyday life. This will involve the shift from perception of a teacher as a pure link for the information transmission, and students as purely the recipients of such information.

Sustainable Development Goal on education as a means for attaining all the other SDGs

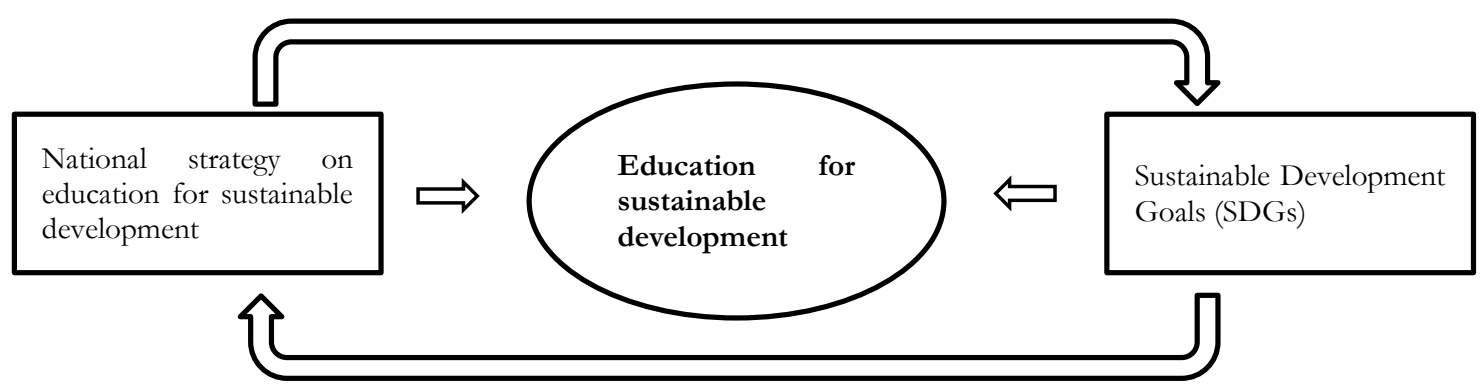

Integration of SDGs to the National strategy on education as a base for reform

Figure 2. Integration of SDGs to the National strategy on EDS

\section{Conclusions}

Promoting the sustainable development is currently a key global issue posing a challenge to all of us on personal, professional and political levels. Indisputable is the fact that education plays a major role in this path. The global sustainable development goals can only be achieved through personal transformation and shift in consciousness on the 
individual level, where it (education) should play an important role. Providing education can be attributed to a fundamental global Sustainable Development Goal, underlying the other Goals and serving as a pledge of their successful implementation.

ESD is education with interdisciplinary nature aimed at addressing the issues such as climate change, poverty and sustainable production, so that the students can understand and meet the challenges of the dramatically changing world. The traditional one-way transfer of knowledge is no longer sufficient to inspire the students to behave as responsible citizens.

This paper suggests a number of competencies, which must serve as a basis for ESD, as well as application of the multiple intelligence theory as a mechanism for implementing the competencies derived by students from ESD at the basic education level. It is proved that security competencies in the broadest sense (covering all levels, from personal to the global space) should also be included in the modern educational process.

As for the university education, it is required to explain the concept of "sustainability" to all specialties without exception, including the political scientists, engineers and others. This is particularly important for training of experts dealing with the economic law issues. A lack of economic analysis in modern legal studies and development of regulations results in writing and adoption of idle laws hazardous for the country.

To upgrade the education system in Ukraine, it is appropriate to develop the National Strategy on Education for Sustainable Development and its implementation plan based on the global Sustainable Development Goals. It is required to switch from traditional education to the model focused on sustainable development with the underlying extensive interdisciplinary knowledge based on an integrated approach to the development of society, economy, and environment. Implementation of this strategy should consider the adaptive nature of the regional education component, in particular the economic features of a relevant region.

It is important to focus on the learning processes underlying the circular economy.

\section{References}

Agenda (2030). Education for sustainable development in the framework of the 2030 Agenda for Sustainable Development. Retrieved from http://undocs.org/A/C.2/72/L.45 [in English].

Barth, M., Godemann, J., Rieckmann, M., Stoltenberg, U. (2007). Developing key competencies for sustainable development in higher education. Int. J. Sustain. High. Educ. 2007, 8, 416-430 [in English].

Barth, M. (2007). Gestaltungskompetenz durch Neue Medien? Die Rolle des Lernens mit Neuen Medien in der Bildung für nachhaltige Entwicklung. Berliner Wissenschafts-Verlag, Berlin 2007 [in German].

Cebrián, G., Junyent, M. (2015). Competencies in Education for Sustainable Development: Exploring the student teachers' views. Sustainability 2015, 7, 2768-2786 [in English].

Doroshkevych, A.S. (2012). Suspil'stvo spozhyvanya moral'no-sotsial'ni naslidky [Society of consumer moral and social consequences]. Visnyk Natsional'noho universytetu «Yurydychna akademiya Ukrayiny imeni Yaroslava Mudroho», 2012. Retrieved from https://cyberleninka.ru/article/n/suspilstvospozhivannya-moralno-sotsialni-naslidki [in Ukrainian].

Eco-Schools (2019). Retrieved from https://www.ecoschools.global [in English].

Eco-schools. Keep Britain Tidy (2019). Retrieved from https://www.eco-schools.org.uk [in English].

Gardner, H. (2017). Struktura Razuma. Teoriya mnozhestvennogo intellekta [Structure of Reason. Theory of Multiple Intelligence]. M., St. Petersburg., K .: Williams, 2007. 512, 3 [in English]. 
Glasser, H., Hirsh, J. (2016). Toward the Development of Robust Learning for Sustainability Core Competences. Sustainability: The Journal of Recor, 2016, 9(3), 121-134 [in English].

Haan, G. (2002). Was ist Bildung für Nachhaltigkeit? In: F. Brickwedde, U. Peters: Umweltkommunikation. Vom Wissen zum Handeln.Berlin 2002, 259-267 [in English].

Harenberg, D. (2001). Bildung für nachhaltige Entwicklung- Entdeckungen im schulischen Alltag und gemeinsames Reformbestreben. In: H. Gärtner, G. Hellberg-Rode (Hrsg.): Umweltbildung \& nachhaltige Entwicklung. Band 1: Grundlagen. Schneider Verlag Hohengehren, Baltmannsweiler 2001 [in German].

Loughborough University. Retrieved from http://www.lboro.ac.uk/enterprise/startup-lab/ [in English].

Mochizuki, Y., Fadeeva, Z. (2010). Competences for sustainable development and sustainability: Significance and challenges for ESD. Int. J. Sustain. High. Educ. 2010, 11, 391-403 [in English].

Natsional'na dopovid' «Tsili Staloho Rozvytku: Ukrayina» [National Report «Sustainable Development Goals: Ukraine»]. Retrieved from http://un.org.ua/images/SDGs_NationalReportUA_Web_1.pdf [in Ukrainian].

Paryz'ka uhoda (2015). Paryz'ka uhoda: Mizhnarodnyy dokument [Paris Agreement: International Document]. Retrieved from http://zakon.rada.gov.ua/laws/show/995_161 [in Ukrainian].

Petrakov, Y. «Brytans'ki universytety evolyutsionuvaly razom zi svoyeyu hromadoyu. My mayemo zrobyty te same» [«British universities evolved along with their community. We have to do the same»] Kul'tura i kreatyvnist'. Retrieved from https://www.culturepartnership.eu/ua/article/yaroslavpetrakov [in Ukrainian].

Podger, D.M., Mustakova-Possardt, E., Reid, A. (2010). A whole-person approach to educating for sustainability. Int. J. Sustain. High. Educ. 2010, 11, 339-352 [in English].

Reid, A., Dahlgren, M., Dahlgren, L., Petocz, P. (2011). From Expert Student to Novice Professional; Springer: New York, NY, USA, 2011 [in English].

Stratehiya (2015). Pro Stratehiyu staloho rozvytku «Ukrayina - 2020» [On Sustainable development strategy 'Ukraine - 2020'] Retrieved from http://zakon.rada.gov.ua/laws/show/5/2015/print [in Ukrainian].

Summers, M., Childs, A., Corney, G. (2005). Education for sustainable development in initial teacher training: Issues for interdisciplinary collaboration, Environmental Education Research, 11(5), 623647 [in English].

The Ministry of Environmental Protection of Republic of Croatia (2011). Action plan for education for sustainable development. Retrieved from http://odraz.hr/en/publications/publications/actionplan-for-education-for-sustainable-development [in English].

Tsili (2016). Tsili staloho rozvytku 2016-2030 [Sustainable Development Goals 2016-2030] Retrieved from http://www.un.org.ua/ua/tsili-rozvytku-tysiacholittia/tsili-staloho-rozvytku [in Ukrainian].

UNESCO (2014). UNESCO Roadmap for Implementing the Global Action Programme on Education for Sustainable Development. Retrieved from http://unesdoc.unesco.org/images/0023/002305/230514e.pdf [in English].

UNESCO (2018). Global Action Programme on Education for Sustainable Development. Retrieved from http://unes $f$ doc.unesco.org/images/0024/002462/246270e.pdf [in English].

UNESCO (2018). Issues and trends in Education for Sustainable Development. UNESCO Publishing. Retrieved from http://unesdoc.unesco.org/images/0026/002614/261445e.pdf [in English].

Ursul A.D., Ursul T.A. (2016). Klyuchevaya rol' obrazovaniya v dostizhenii Tseley ustoychivogo razvitiya [The key role of education in achieving the Sustainable Development Goals]. Sotsiodinamika. 2016, № 4, 1 - 18 [in Russian].

Vare, P., Arro, G., Hamer, A.D., Gobbo, G.D., Vries, G.D., Farioli, F., Kadji-Beltran, C. et. al (2019). Devising a competence-based training program for educators of sustainable development: Lessons learned. Sustainability 2019, 11 [in English].

Waltner, E.M., Rieß, W., Mischo, C. (2019). Development and validation of an instrument for measuring student sustainability competencies. Sustainability 2019, 11 [in English].

Wiek, A., Withycombe, L., Redman, C.L. (2011). Key competencies in sustainability: A reference framework for academic program development. Sustain. Sci. 2011, 6, 203-218 [in English].

Wilhelm, S., Förster, R., Zimmermann, A.B. (2019). Implementing competence orientation: Towards constructively aligned education for sustainable development in university-level teaching-andlearning. Sustainability 2019, 11 [in English]. 